\title{
STUDI KELAYAKAN WADUK CIKAWARI 2A DAN 5A DALAM RANGKA PEMENUHAN KEBUTUHAN AIR KOTA BANDUNG
}

\section{FEASIBILITY STUDY OF CIKAWARI 2A AND 5A RESEVOIR TO FULFILL THE WATER DEMAND FOR BANDUNG CITY}

\author{
Cleon Christopher1), Doddi Yudianto'), Albert Wicaksono ${ }^{1)^{*}}$ \\ 1) Universitas Katolik Parahyangan, Jl. Ciumbuleuit No. 94, Bandung, Indonesia \\ *Correspondent email: albert.wicaksono@unpar.ac.id
}

Diterima: 29 Januari 2021; Direvisi: 16 Maret 2021; Disetujui: 19 April 2021

\begin{abstract}
The water need in the Northern area of Bandung City was predicted to be $2.49 \mathrm{~m}^{3} / \mathrm{s}$ in 2040. The government responded to this issue by planning the construction of several reservoirs in the Cikapundung watershed. A previous study suggested three potential locations, i.e., Cikukang 2, Cikawari 2A, and Cikawari 5A reservoir. Since Cikawari 2A and Cikawari 5A are located on the same Cikawari river, three construction alternatives, i.e., a single reservoir of Cikawari $2 A$, a single reservoir of Cikawari 5A, and cascade reservoir Cikawari $2 A+5 A$ are proposed. Each alternative has its own advantages and limitations, thus evaluation of the best construction alternative needs to be carried out. The evaluation was conducted based on their reliable service in supplying water to Bandung City. This evaluation was analyzed by comparing the projected water demand following population growth and water availability derived from the rainfall-runoff model, NRECA. The analysis was conducted using two variations of dam height and reservoir capacity for each alternative. Based on the analysis results, the single reservoir of Cikawari $2 A$ with $45 \mathrm{~m}$ of dam's height was chosen as the most suitable alternative. It can supply $0.56 \mathrm{~m}^{3} / \mathrm{s}$ of water and provide water for $30.4 \%$ of the citizens in 2020, and decrease to $30.15 \%$ in 2040. However, it was also found that the reservoir could only supply $0.44 \mathrm{~m}^{3} / \mathrm{s}$ of water during the dry period. These results showed that the construction of the reservoir itself could not meet the total water demand. Therefore, another alternative is required to closing the gap in water demand.
\end{abstract}

Keywords: Cikapundung watershed, water supply, Cikawari reservoir, reservoir simulation, service reliability

\begin{abstract}
ABSTRAK
Kebutuhan air di Kota Bandung bagian Utara diprediksi menjadi 2,49 $\mathrm{m}^{3} / \mathrm{s}$ pada tahun 2040. Penambahan jumlah kebutuhan air ini direspon oleh pemerintah Kota Bandung dengan membangun sejumlah waduk di Daerah Aliran Sungai Cikapundung. Berdasarkan studi terdahulu terdapat tiga lokasi potensial, yaitu Waduk Cikukang 2, Waduk Cikawari 2A, dan Cikawari 5A. Teridentifikasi bahwa lokasi Waduk Cikawari 2A dan 5A berada pada satu aliran sungai Cikawari yang sama, sehingga memunculkan tiga alternatif pembangunan waduk, yaitu pembangunan waduk tunggal Cikawari $2 A$, waduk tunggal Cikawari 5A, dan waduk kaskade Cikawari 2A+5A. Ketiga alternatif tersebut memiliki keunggulan dan keterbatasannya masing-masing sehingga diperlukan suatu studi untuk menentukan alternatif yang paling layak dibangun berdasarkan tingkat pemenuhan airnya. Evaluasi tingkat pemenuhan air dilakukan dengan membandingkan kebutuhan air yang diproyeksikan sesuai pertambahan penduduk dan ketersediaan air yang diturunkan berdasarkan model hujan-limpasan NRECA. Analisis dilakukan pada beberapa kemungkinan tinggi dan kapasitas waduk pada setiap alternatif pembangunan hingga diperoleh suatu nilai tingkat layanan maksimum waduk. Berdasarkan hasil simulasi, alternatif pembangunan waduk tunggal Cikawari $2 \mathrm{~A}$ dengan pelimpah setinggi $45 \mathrm{~m}$ merupakan alternatif terpilih. Pemanfaatan waduk tunggal Cikawari $2 A$ mampu memenuhi kebutuhan air sebesar 0,562 $\mathrm{m}^{3} / \mathrm{s}$ untuk 30,4\% penduduk pada tahun 2020 dan berkurang menjadi 30,15\% pada tahun 2040. Namun, pada kondisi tahun kering air yang tersedia hanya mampu memenuhi kebutuhan air sebesar 0,440 m33. Hasil analisis ini menunjukkan bahwa pembangunan waduk di DAS Cikapundung ternyata tidak dapat memenuhi target kebutuhan air secara penuh sehingga diperlukan alternatif lain untuk mencapai target pemenuhan yang diharapkan.
\end{abstract}

Kata Kunci: DAS Cikapundung, penyediaan air baku, Waduk Cikawari, simulasi waduk, tingkat pelayanan 


\section{PENDAHULUAN}

Perubahan iklim dan perkembangan aktivitas ekonomi suatu daerah dapat berdampak pada peningkatan kebutuhan air di suatu kawasan, yang terkadang memunculkan pengambilan air permukaan dan air tanah secara berlebihan (Yoshida et al., 2013; Nurchayono et al., 2016). Di sisi lain, maraknya konversi daerah hutan atau kawasan resapan air menjadi daerah pertanian dan permukiman berdampak pada semakin sempitnya luasan daerah resapan air yang berdampak pada meningkatnya limpasan permukaan dan berkurangnya cadangan air tanah (Julian et al., 2011).

Permasalahan sumber air baku di Kota Bandung, Provinsi Jawa Barat, merupakan salah satu contoh masalah yang kerap terjadi saat perkembangan suatu kawasan tidak diimbangi dengan konservasi sumber daya air di kawasan sekitarnya. Sebagaimana diungkapkan oleh Rubianto (2003) dan Sabar (2006), air permukaan dan air tanah di Daerah Aliran Sungai (DAS) Cikapundung merupakan salah satu sumber daya air potensial yang dapat dimanfaatkan sebagai sumber air baku guna memenuhi kebutuhan air masyarakat di Kota Bandung. Namun, perubahan tata guna lahan di kawasan DAS Cikapundung telah mempengaruhi fungsi konservasi air tanah dan debit aliran Sungai Cikapundung karena berkurangnya luas kawasan resapan air (Maria dan Lestiana, 2014; Wibowo, 2005; Kuntoro et al., 2016).

Kondisi yang disampaikan di atas menyebabkan peningkatan kebutuhan air di Kota Bandung tidak dapat terpenuhi jika hanya mengandalkan pengambilan langsung dari aliran permukaan Sungai Cikapundung. Dengan demikian, diperlukan sejumlah waduk di DAS Cikapundung yang diharapkan dapat menjadi sumber air baku bagi kota Bandung, secara khusus pada Bandung bagian Utara. DAS Cikapundung dipilih menjadi salah satu lokasi potensial bagi penyediaan sumber air baku dengan waduk mengingat curah hujan di kawasan ini terjadi hampir sepanjang tahun sehingga dapat diandalkan untuk menjaga volume air tertampung (Tanuwijaya et al., 2018).

Rencana pembangunan waduk ini ditindaklanjuti dalam studi perencanaan induk (masterplan) penyediaan air baku untuk Kota Bandung oleh Euroconsult Mott MacDonald (2014). Studi tersebut membagi Kota Bandung menjadi 4 sub-kawasan pelayanan, yaitu Kota Badaksinga, Kota Timur, Kota Utara, dan Ujung Berung. Khusus untuk kawasan Kota Bandung bagian Utara, proyeksi kebutuhan air pada tahun 2040 mencapai $2,49 \mathrm{~m}^{3} / \mathrm{s}$ yang akan dipenuhi dari air tanah, mata air, sungai, serta potensi waduk di DAS Cikapundung. Studi tahun 2014 ini mengusulkan perencanaan lima buah lokasi potensi waduk di kawasan DAS Cikapundung, yang kemudian ditindaklanjuti dengan studi tahun 2019 sehingga mengerucut menjadi tiga buah lokasi potensi waduk, yaitu Cikawari 2A, Cikawari 5A, dan Cikukang 2 (Rencana Cipta Mandiri, 2019). Lokasi ketiga potensi waduk ditunjukkan pada Gambar 1.

Penelitian kali ini bertujuan untuk mengkaji lebih lanjut alternatif pembangunan waduk Cikawari 2A dan 5A sebagai waduk tunggal Cikawari 2A, waduk tunggal Cikawari 5A, atau waduk kaskade Cikawari 2A dan 5A mengingat kedua waduk berada pada daerah aliran sungai yang sama. Kajian pada penelitian ini berfokus pada aspek teknis berdasarkan tingkat pelayanan pemenuhan air, tanpa mengesampingkan kondisi geologi, dampak lingkungan, dan sosial-ekonomi yang juga telah dipertimbangkan dalam pemilihan lokasi ketiga waduk. Tingkat pelayanan pemenuhan air dari ketiga alternatif waduk akan dievaluasi untuk menentukan alternatif yang paling layak dalam memenuhi kebutuhan air Kota Bandung bagian Utara.

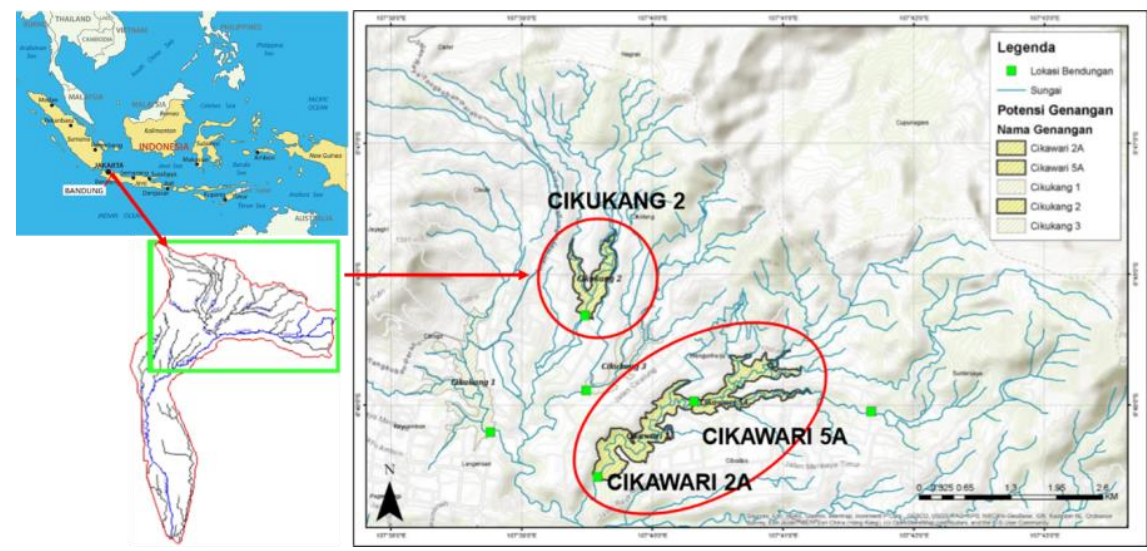

Sumber: Rencana Cipta Mandiri, 2019

Gambar 1 Lokasi potensi Waduk Cikukang 2, Cikawari 2A dan Cikawari 5A 


\section{METODOLOGI}

Secara umum, studi ini terdiri dari tahap persiapan yaitu studi literatur dan pengumpulan data, analisis ketersediaan dan kebutuhan air, simulasi waduk, penentuan alternatif pembangunan waduk, dan analisis pola operasi waduk. Skema metodologi studi disajikan pada Gambar 2.

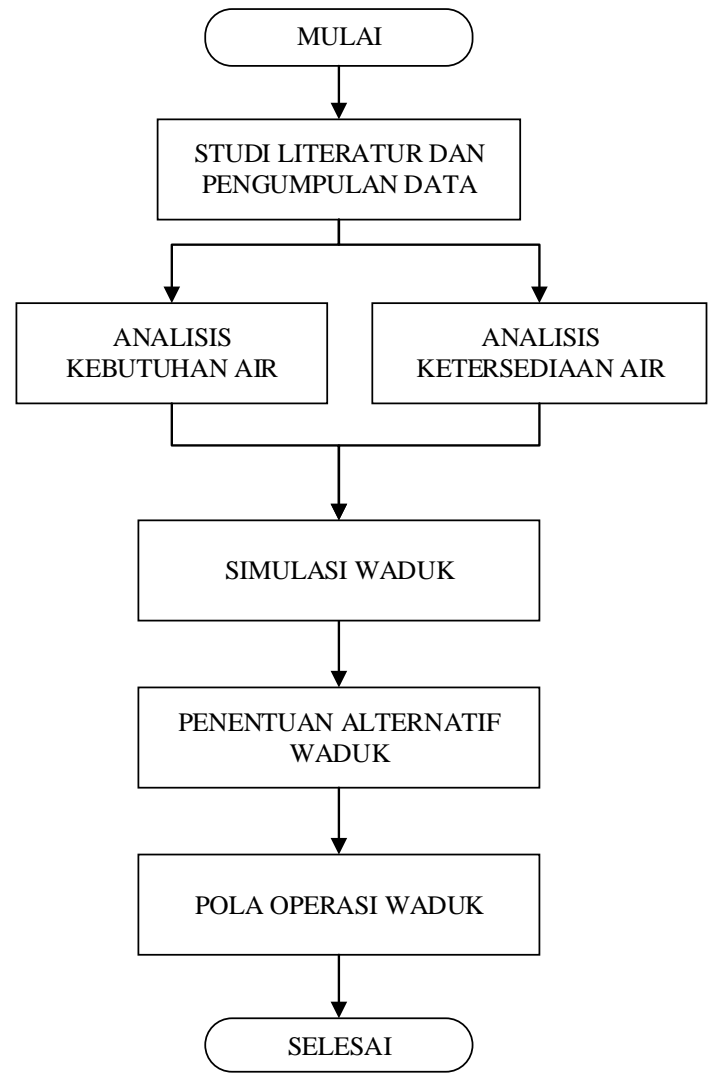

Gambar 2 Skema metodologi

\section{Tahap Persiapan}

Tahap persiapan dari penelitian ini adalah dengan melakukan studi yang meliputi identifikasi permasalahan dan hasil studi terdahulu. Data yang berhasil dikumpulkan mencakup data curah hujan harian dari tahun 1998 sampai 2018, data debit harian Sungai Cikapundung di Pos Maribaya dari tahun 2003 sampai 2009, dan data karakteristik waduk. Data tersebut dipergunakan untuk memperbaharui data dan menunjang analisis yang akan dilakukan pada penelitian ini. Data hidroklimatologi dan curah hujan diperoleh dari Badan Meteorologi, Klimatologi, dan Geofisika Kota Bandung (2019). Sementara data karakteristik waduk diperoleh dari Laporan Hidrologi dan Hidraulika Detail Desain Tahap I Bendungan Cikapundung (Rencana Cipta Mandiri, 2019).

\section{Analisis Ketersediaan Air}

Analisis ketersediaan air dilakukan menggunakan model NRECA berdasarkan data hujan bulanan, serta data debit pengamatan untuk kalibrasi parameter model. Model NRECA dikembangkan oleh Norman H. Crawford pada tahun 1985 (Crawford, 1985). Data-data yang diperlukan untuk melakukan analisis debit menggunakan model NRECA antara lain: data hujan bulanan, data klimatologi, data pencatatan debit, serta luas dan kondisi DAS. Berdasarkan data yang ada, metode NRECA akan mensimulasikan proses hujan menjadi limpasan dengan melakukan kalibrasi parameter nominal, index groundwater storage (GWF), dan Percent of Sub Surface (PSUB) sehingga perhitungan debit yang dihasilkan mendekati debit pencatatan sesungguhnya.

\section{Analisis Kebutuhan Air}

Analisis kebutuhan air dihitung mengikuti proyeksi kebutuhan domestik dan kawasan perkotaan (domestic and municipal demand). Kebutuhan air dihitung berdasarkan hasil perkalian antara prediksi jumlah penduduk dengan standar kebutuhan air. Jumlah penduduk di masa mendatang diprediksi berdasarkan rumus geometrik laju pertumbuhan penduduk (Badan Pusat Statistik, 2010):

$$
P_{i}=P_{0}(1+r)^{n}
$$

Dengan:

$\mathrm{P}_{\mathrm{i}}=$ jumlah penduduk pada tahun ke-i

$\mathrm{P}_{0}=$ jumlah penduduk pada tahun awal

$r$ = laju pertumbuhan penduduk

$\mathrm{n}$ = jangka waktu

Berdasarkan data laju pertumbuhan penduduk tahun 2011 hingga 2019 (BPS Kota Bandung, 2019a) diperoleh persamaan regresi laju pertumbuhan penduduk pada tahun ke-i sebagai berikut (Christopher, 2020):

$$
r=0,0079 * \operatorname{EXP}(-0,174 * i)
$$

Apabila proyeksi jumlah penduduk pada tahun ke-i dihitung berdasarkan jumlah penduduk pada tahun sebelumnya (i-1), maka nilai $\mathrm{n}=1$ dan jumlah penduduk pada tahun ke-i dapat diprediksi menggunakan persamaan:

$\mathrm{P}_{\mathrm{i}}=\mathrm{P}_{\mathrm{i}-1}(1+(0,0079 * \operatorname{EXP}(-0,174 * \mathrm{i})))$

Sementara itu, standar kebutuhan air yang digunakan dalam penelitian ini didapatkan dari studi Bulk Water Supply Master Plan (Euroconsult Mott MacDonald, 2014), dengan standar sebagai berikut:

- Kebutuhan domestik 190 L/orang/hari untuk kota metropolitan. 
- Kebutuhan perkotaan atau lain-lain sebesar $30 \%$ dari kebutuhan domestik untuk kota metropolitan.

\section{Simulasi Waduk}

Tahap selanjutnya adalah simulasi waduk yang akan menggunakan data karateristik waduk serta data dari hasil analisis model NRECA, kebutuhan air, data hujan, dan potensi evapotranspirasi (PET). Hasil analisis simulasi waduk kemudian dievaluasi dan digunakan sebagai dasar dalam penentuan alternatif pembangunan waduk. Pada tahap ini dilakukan simulasi pada tiga alternatif pembangunan waduk dengan beberapa kemungkinan tinggi pelimpah waduk yang dapat dibangun. Sebagaimana disajikan pada Gambar 2, skenario yang disimulasikan pada studi ini terdiri dari:

- Skenario 1: Waduk tunggal Cikawari 2A atau Waduk Cikawari 5A dengan tampungan efektif

- Skenario 2: Waduk tunggal Cikawari 2A atau Waduk Cikawari 5A dengan tampungan maksimum

- Skenario 3: Waduk kaskade Cikawari 2A dan 5A dengan tampungan maksimum

Dari ketiga skenario tersebut, akan dipilih satu alternatif pembangunan waduk yang dilakukan berdasarkan persentase jumlah penduduk yang dapat terlayani oleh waduk tersebut.

\section{Pola Operasi Waduk}

Tahap terakhir adalah analisis Pola Operasi Waduk (POW). Menurut Peraturan Menteri PUPR No. 27/2015, POW merupakan tata cara pengeluaran air dari waduk sesuai dengan kondisi volume dan/atau elevasi waduk yang dilengkapi dengan lengkung batas operasi normal bawah dan normal atas. POW dibuat dengan tujuan untuk memeriksa kesiapan waduk dalam menghadapi ketersediaan air pada kondisi kering, normal, dan basah. Penentuan kondisi kering, normal, dan basah tersebut ditetapkan berdasarkan nilai aliran pada probabilitas $80 \%$ (kondisi kering), probabilitas $50 \%$ (kondisi normal), dan probabilitas 20\% (kondisi basah) sesuai kurva durasi berdasarkan data historis hujan dan/atau debit.

\section{HASIL DAN PEMBAHASAN}

\section{Potensi Air DAS Cikawari 2A dan 5A}

Dari data hujan yang berhasil dikumpulkan, diperoleh curah hujan tahunan seperti ditunjukkan pada Gambar 3. Berdasarkan analisis kurva durasi diperoleh curah hujan pada tahun basah, normal, dan kering sebesar 3324 mm, 2796 mm, dan 2333 mm. Pada Gambar 3 juga terlihat bahwa curah hujan tahunan pada tahun 2003 hingga 2006 lebih rendah dari curah hujan pada tahun kering. Kondisi ini perlu menjadi perhatian karena dimungkinkan terjadinya kondisi kering cukup ekstrim di DAS Cikapundung yang akan berdampak pada penentuan pola operasi waduk.

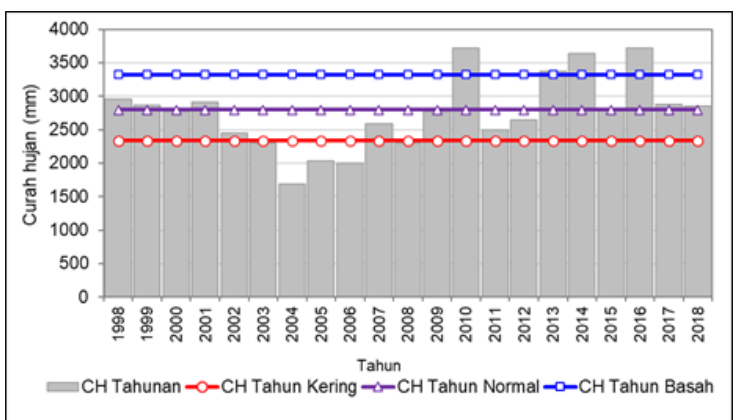

Gambar 3 Curah hujan tahunan

Hasil perhitungan debit sintetik pada DAS Cikawari 2A dan 5A berdasarkan metode NRECA disajikan pada Gambar 4 dan Gambar 5. Sementara hasil perhitungan debit andalan pada masingmasing DAS disajikan pada Tabel 1.

Berdasarkan hasil analisis yang dirangkum pada Tabel 1 diketahui nilai debit andalan pada kedua lokasi potensi waduk tidak mampu mencapai nilai target kebutuhan air sebesar 2,49 $\mathrm{m}^{3} / \mathrm{s}$ (Euroconsult Mott MacDonald, 2014). Oleh karena itu, pembangunan waduk di kedua lokasi ini menjadi suatu kebutuhan dalam meningkatkan potensi air yang tersedia untuk mencapai target kebutuhan air yang direncanakan.

\section{Prediksi Kebutuhan Air Kota Bandung}

Analisis kebutuhan air dilakukan untuk mengetahui kebutuhan air penduduk Kota Bandung yang terdiri dari kebutuhan air penduduk (domestik) dan kawasan perkotaan (munisipal). Kebutuhan air dihitung berdasarkan pertambahan jumlah penduduk dan standar kebutuhan air perkotaan.

Berdasarkan hasil analisis proyeksi laju pertumbuhan penduduk menggunakan persamaan (3) didapatkan prediksi jumlah penduduk untuk Kota Bandung meningkat dari 2.508.000 jiwa pada tahun 2019 menjadi 2.533 .000 jiwa pada tahun 2040 (Sumber: Christopher, 2020

Gambar 6). Hasil prediksi jumlah penduduk seluruh Kota Bandung ini akan digunakan untuk memperkirakan kebutuhan air penduduk Kota Bandung bagian Utara yang dihitung berdasarkan rasio debit kebutuhan air Kota Bandung bagian Utara dengan total kebutuhan air Kota Bandung secara proporsional. Berdasarkan proporsi kebutuhan air tersebut, maka proyeksi kebutuhan air Kota Bandung bagian Utara pada tahun 2040 
adalah sebesar 1,86 m³ $/ \mathrm{s}$ (Tabel 2). Hasil proyeksi tersebut memiliki perbedaan dengan proyeksi studi Bulk Water Supply Master Plan (Euroconsult Mott MacDonald, 2014) karena perhitungan jumlah penduduk dihitung berdasarkan data pertumbuhan penduduk terbaru Kota Bandung rata-rata sebesar $0,43 \%$, sesuai data jumlah dan laju pertembuhan penduduk di Kota Bandung (BPS Kota Bandung, 2019a dan 2019b).

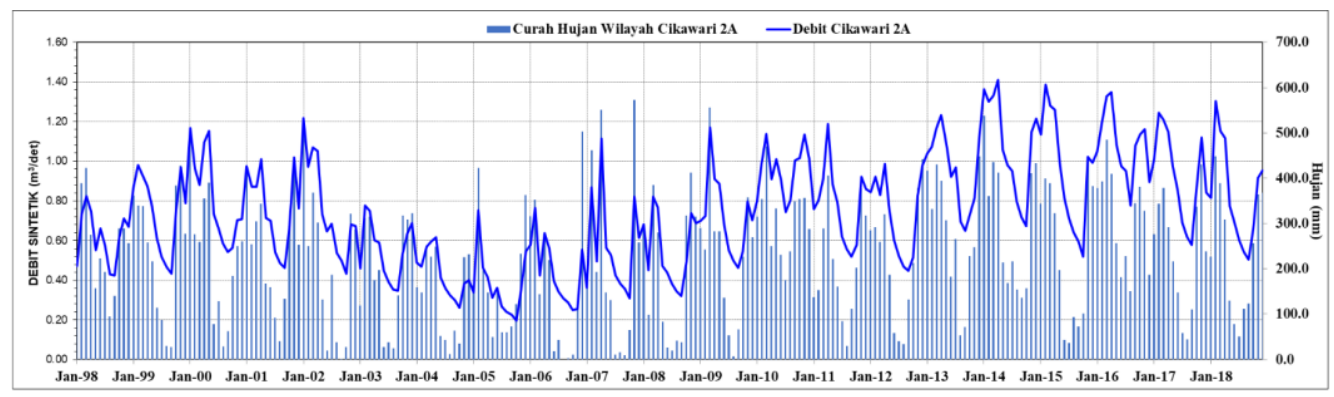

Gambar 4 Debit Sintetik Waduk Tunggal Cikawari 2A

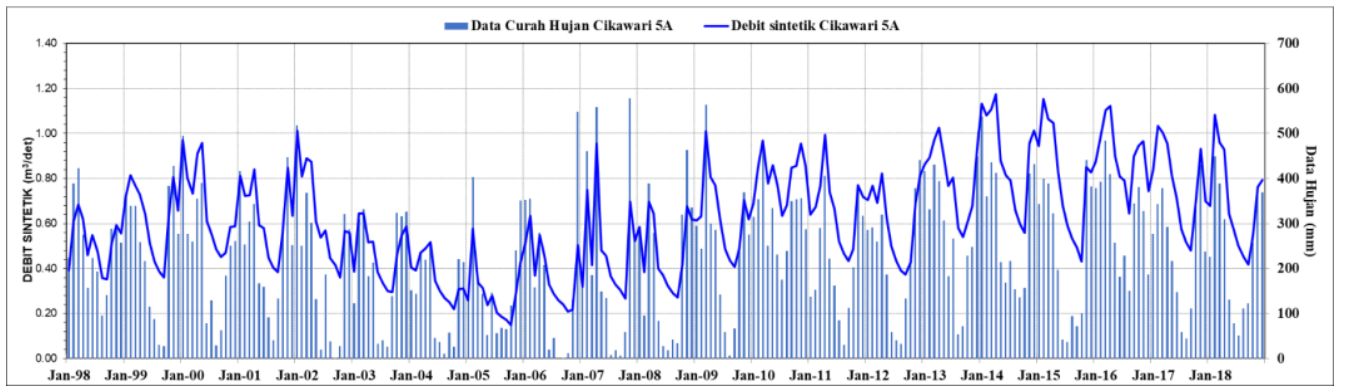

Gambar 5 Debit Sintetik Waduk Tunggal Cikawari 5A

Tabel 1 Rangkuman Debit Andalan Sungai Cikawari

\begin{tabular}{c|c|c|c}
\hline Debit Andalan & Cikawari 2A $\left(\mathrm{m}^{3} / \mathrm{s}\right)$ & Cikawari 5A $\left(\mathrm{m}^{3} / \mathrm{s}\right)$ & Total $\left(\mathrm{m}^{3} / \mathrm{s}\right)$ \\
\hline $\mathrm{Q} 50 \%$ & 0,72 & 0,61 & 1,33 \\
\hline $\mathrm{Q} 80 \%$ & 0,48 & 0,40 & 0,88 \\
\hline $\mathrm{Q} 90 \%$ & 0,38 & 0,32 & 0,70 \\
\hline $\mathrm{Q} 95 \%$ & 0,32 & 0,27 & 0,59 \\
\hline
\end{tabular}

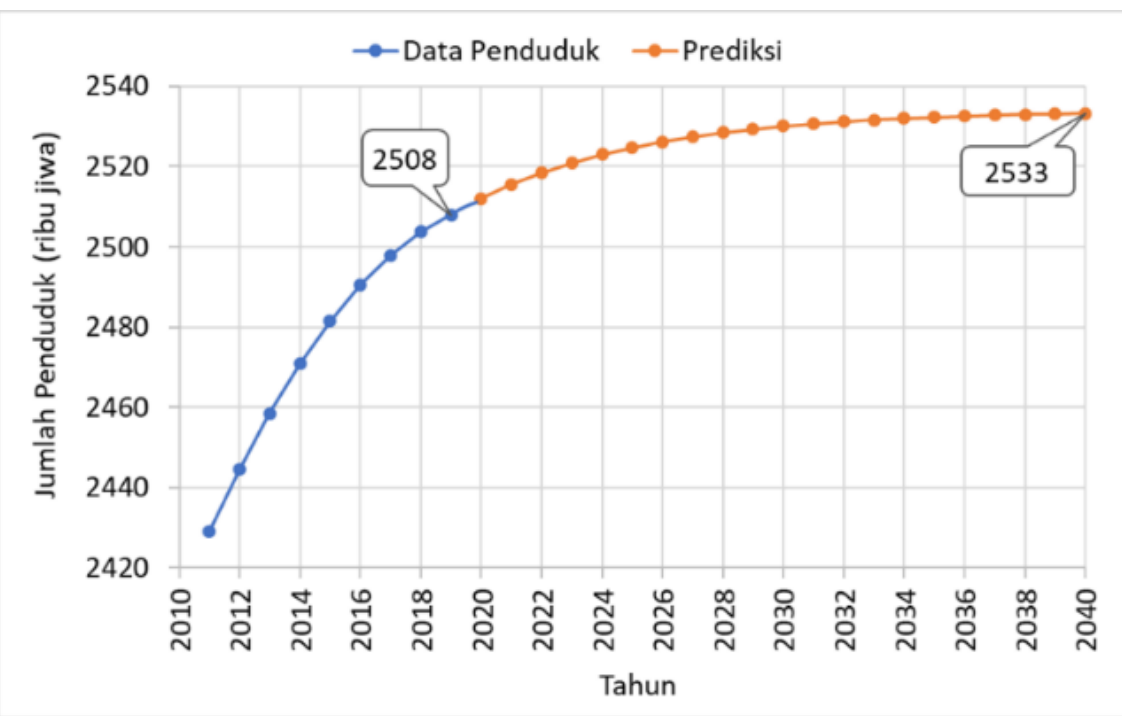

Sumber: Christopher, 2020 
Gambar 6 Prediksi Jumlah Penduduk Kota Bandung

Tabel 2 Kebutuhan Air Kota Bandung Bagian Utara

\begin{tabular}{c|c|c}
\hline Tahun & $\begin{array}{c}\text { Penduduk Kota Bandung bagian Utara } \\
\text { (orang) }\end{array}$ & $\begin{array}{c}\text { Kebutuhan Domestik + Perkotaan Kota Bandung } \\
\text { bagian Utara }\left(\mathrm{m}^{3} / \mathrm{s}\right)\end{array}$ \\
\hline 2020 & 646.173 & 1,85 \\
\hline 2025 & 649.441 & 1,86 \\
\hline 2040 & 651.630 & 1,86 \\
\hline
\end{tabular}

\section{Simulasi Waduk Cikawari 2A dan5A}

Simulasi waduk dimulai dengan menggunakan volume tampungan efektif masing-masing bendungan yang diperoleh dari pengukuran pada studi terdahulu (Rencana Cipta Mandiri, 2019). Simulasi waduk dilakukan sesuai skenario dengan kombinasi waduk dan tinggi pelimpah yang telah ditetapkan. Peninggian pelimpah dimaksudkan untuk menambah kapasitas tampungan waduk serta potensi volume air yang dapat dimanfaatkan.

Simulasi dilakukan pada debit outflow maksimal yang menghasilkan tingkat keandalan sebesar 95\% selama periode simulasi sesuai dengan standar keandalan penyediaan air untuk air minum (Pusat Pendidikan dan Pelatihan Sumber Daya Air dan Konstruksi, 2017). Persentase kegagalan dihitung berdasarkan jumlah kejadian dimana air yang tersedia di waduk tidak mampu untuk memenuhi kebutuhan air secara penuh selama periode simulasi waduk. Hasil simulasi waduk pada berbagai skenario ditunjukkan pada Gambar 7 hingga Gambar 11, serta Tabel 3 sampai Tabel 5.

Gambar 7 dan Gambar 8 menunjukkan hasil simulasi skenario-1 dimana masing-masing waduk disimulasikan sebagai waduk tunggal pada kondisi tampungan efektif. Pada skenario-1 ini diketahui bahwa tinggi pelimpah Cikawari 2A setinggi $32 \mathrm{~m}$ dan Cikawari 5A setinggi $41 \mathrm{~m}$. Sebagaimana terlihat pada Tabel 3, debit pengambilan terbesar untuk skenario-1 dihasilkan oleh waduk tunggal
Cikawari 2A dengan debit sebesar $0,49 \mathrm{~m}^{3} / \mathrm{s}$ dengan tingkat layanan $26 \%$.

Hasil simulasi waduk tunggal dengan tampungan maksimum (skenario-2) ditunjukkan pada Gambar 9 dan Gambar 10. Pada skenario ini ditetapkan tinggi pelimpah maksimum Cikawari 2A dan Cikawari 5A setinggi $45 \mathrm{~m}$ sesuai kondisi geologi di lokasi bendungan yang berdekatan dengan Sesar Lembang. Pada skenario-2 ini terlihat bahwa debit pengambilan terbesar untuk skenario2 adalah sebesar $0,56 \mathrm{~m}^{3} / \mathrm{s}$ dengan tingkat layanan 30,4\% yang diberikan oleh waduk tunggal Cikawari 2A sebagaimana disajikan pada Tabel 4.

Hasil simulasi skenario-3 pada kondisi tampungan maksimum dengan skenario waduk kaskade ditunjukkan pada Gambar 11. Skenario ini mensimulasikan tinggi bendungan Cikawari 2A setinggi $25 \mathrm{~m}$ dan Cikawari 5A setinggi $45 \mathrm{~m}$. Tabel 5 menunjukkan hasil simulasi waduk skenario-3, dimana dapat dilihat bahwa debit pengambilan terbesar pada kondisi kaskade ini adalah sebesar $0,53 \mathrm{~m}^{3} / \mathrm{s}$ dengan tingkat layanan $28,58 \%$.

Pada Gambar 7 hingga Gambar 11 terlihat bahwa tampungan waduk mengalami penurunan secara ekstrim dari tahun 2003 hingga 2006, karena pada rentang tahun tersebut terjadi hujan ekstrim rendah dimana nilainya di bawah curah hujan tahun kering seperti ditunjukkan pada Gambar 3.

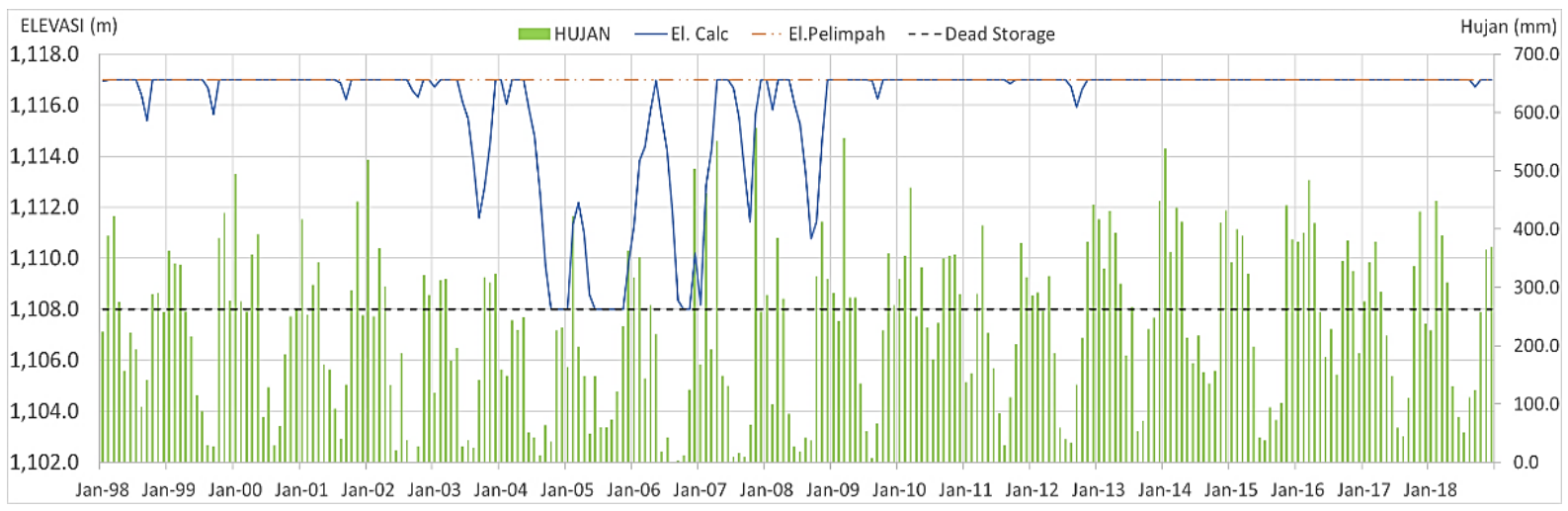

Gambar 7 Simulasi Waduk Tunggal Cikawari 2A pada Skenario 1 


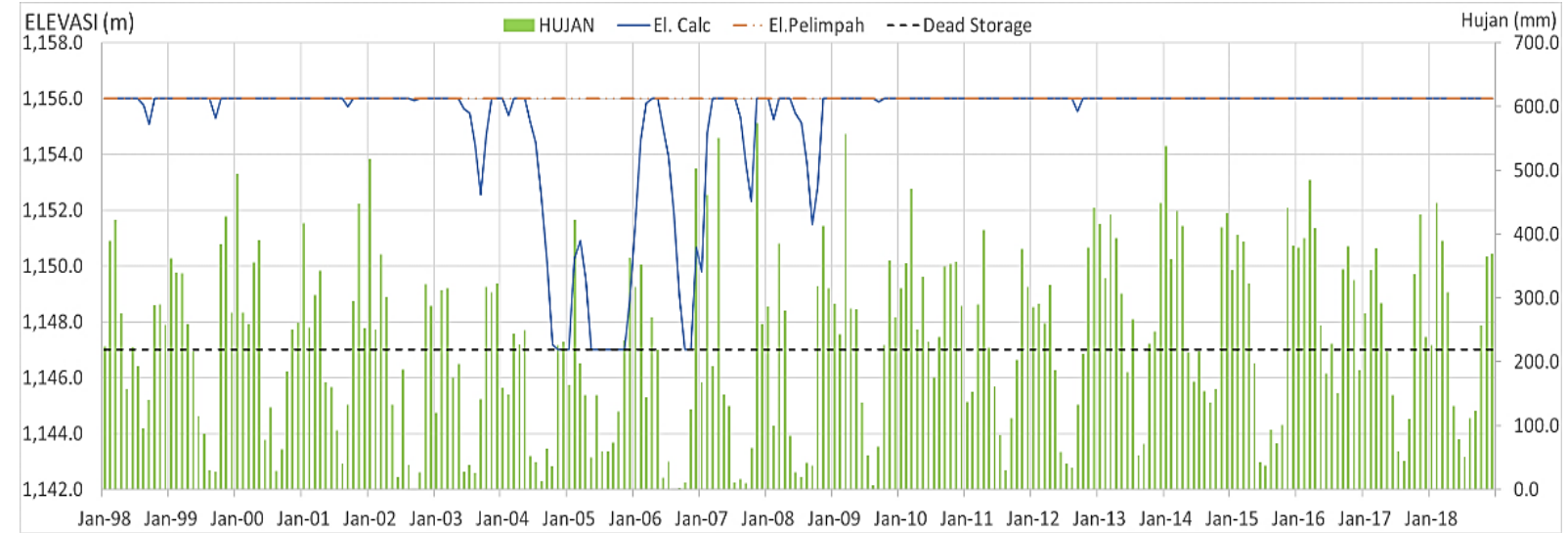

Gambar 8 Simulasi Waduk Tunggal Cikawari 5A pada Skenario 1

Tabel 3 Hasil Simulasi Waduk Skenario 1

\begin{tabular}{c|c|c|c|c|c}
\hline \multirow{2}{*}{ Alternatif } & \multirow{2}{*}{$\begin{array}{c}\text { Tinggi Pelimpah } \\
(\mathrm{m})\end{array}$} & \multirow{2}{*}{$\begin{array}{c}\text { Volume } \\
\text { tampungan } \\
\left(\text { juta } \mathrm{m}^{3}\right)\end{array}$} & \multicolumn{2}{|c|}{ Debit Pengambilan $\left(\mathrm{m}^{3} / \mathrm{s}\right)$} & \multicolumn{2}{c}{$\begin{array}{c}\text { Tingkat Layanan } \\
(\%)\end{array}$} \\
\cline { 4 - 5 } & & 1,90 & 0,560 & 0,490 & 26,00 \\
\hline Cikawari 2A & 32 & 1,42 & 0,460 & 0,376 & 20,00 \\
\hline Cikawari 5A & 41 & & & \\
\hline
\end{tabular}

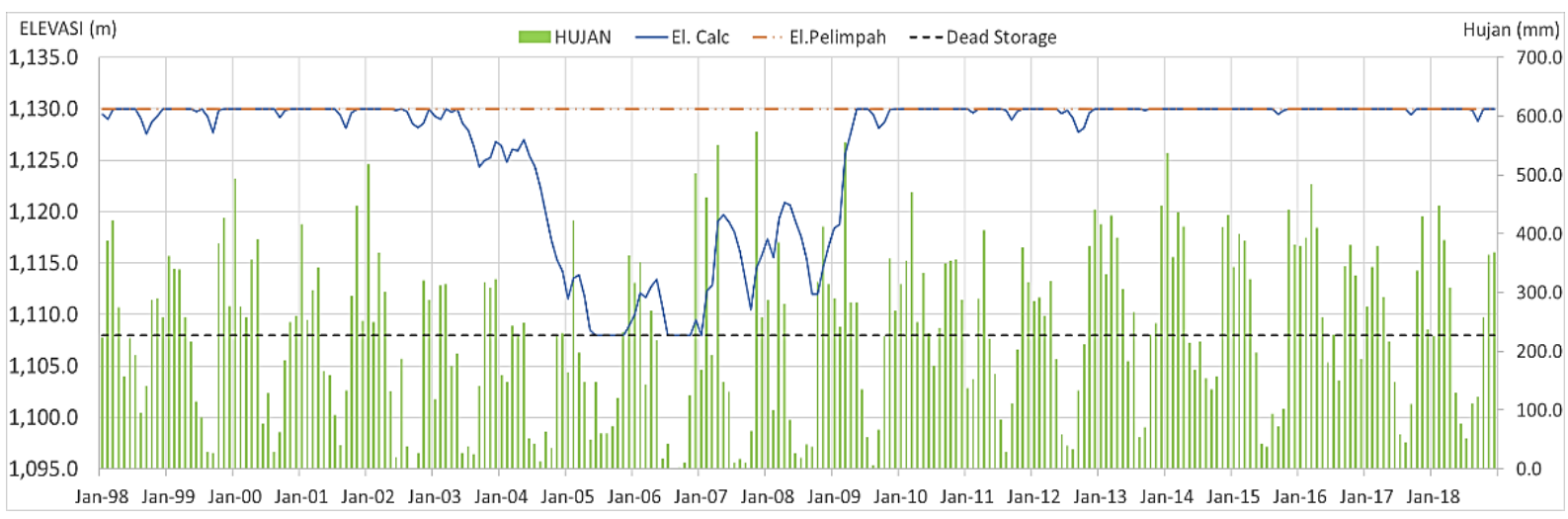

Gambar 9 Simulasi Waduk Tunggal Cikawari 2A pada Skenario 2

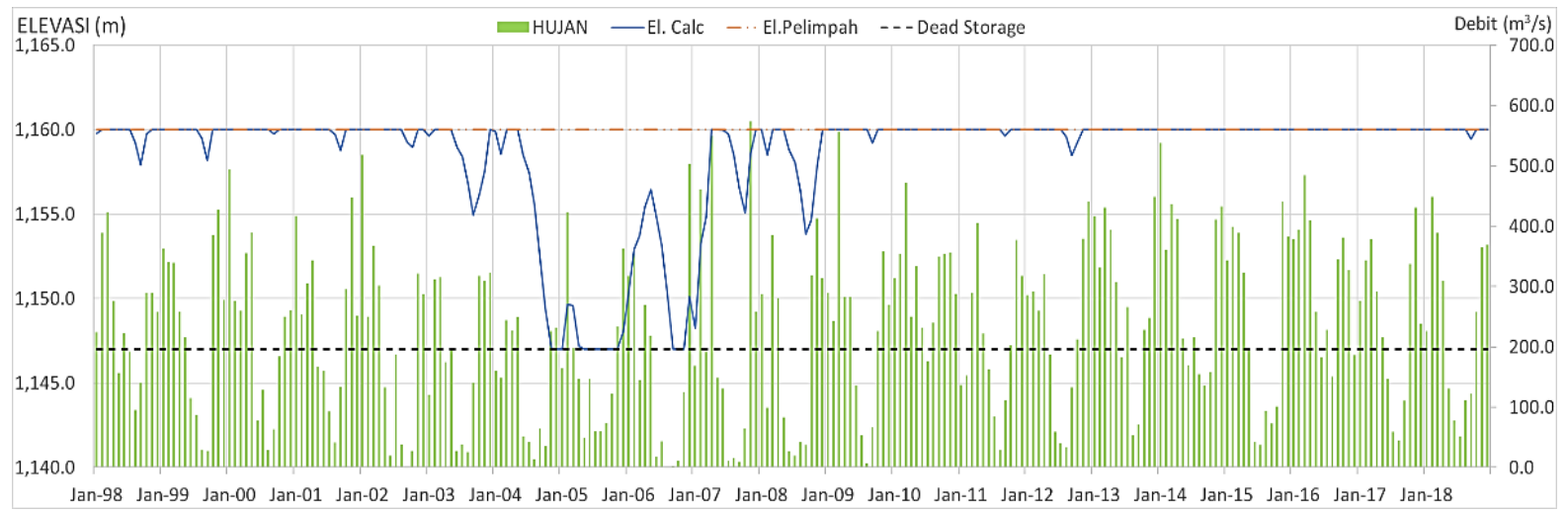

Gambar 10 Simulasi Waduk Tunggal Cikawari 5A pada Skenario 2 
Tabel 4 Hasil Simulasi Waduk Skenario 2

\begin{tabular}{l|c|c|c|c|c}
\hline \multirow{2}{*}{ Alternatif } & \multirow{2}{*}{$\begin{array}{c}\text { Tinggi Pelimpah } \\
(\mathrm{m})\end{array}$} & \multirow{2}{*}{$\begin{array}{c}\text { Volume } \\
\text { tampungan } \\
\left.\text { (juta } \mathrm{m}^{3}\right)\end{array}$} & \multicolumn{2}{|c|}{ Debit Pengambilan $\left(\mathrm{m}^{3} / \mathrm{s}\right)$} & \multirow{2}{*}{$\begin{array}{c}\text { Tingkat Layanan } \\
(\%)\end{array}$} \\
\cline { 4 - 5 } & & 7,83 & 0,620 & 0,562 & 30,40 \\
\hline Cikawari 2A & 45 & 3,61 & 0,489 & 0,419 & 22,65 \\
\hline
\end{tabular}

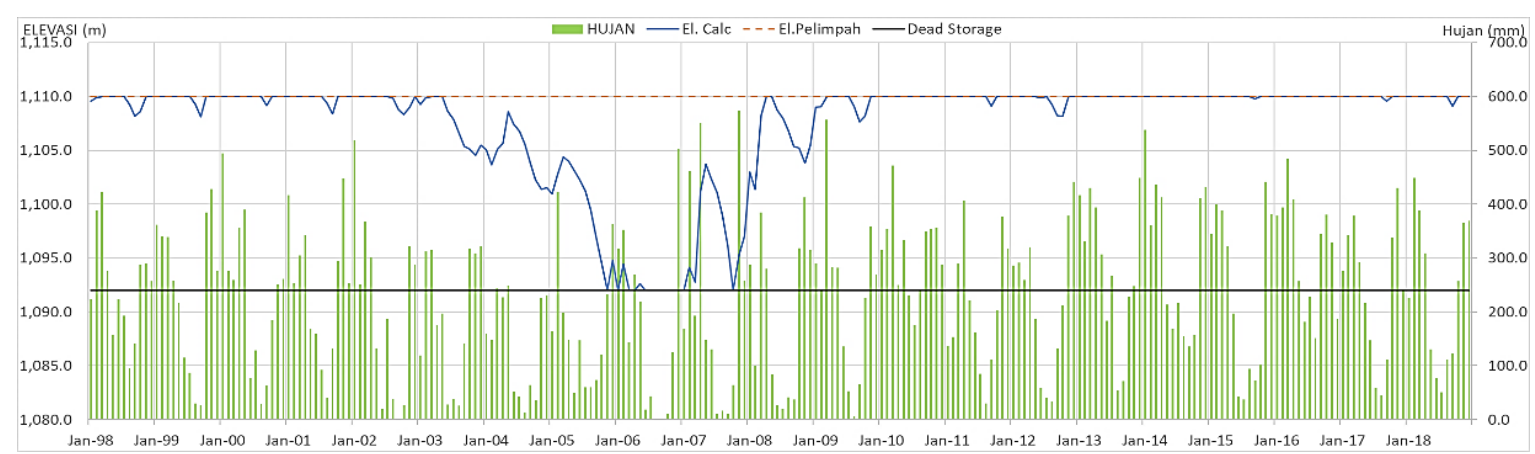

Gambar 11 Simulasi Waduk Kaskade Cikawari 2A+5A sesuai Skenario 3

Tabel 5 Hasil Simulasi Waduk Skenario 3

\begin{tabular}{|c|c|c|c|c|c|c|}
\hline \multirow[b]{2}{*}{ Alternatif } & \multirow{2}{*}{$\begin{array}{l}\text { Tinggi Pelimpah } \\
\text { (m) }\end{array}$} & \multirow{2}{*}{$\begin{array}{c}\text { Volume } \\
\text { tampungan } \\
\left(\text { juta } \mathrm{m}^{3} \text { ) }\right.\end{array}$} & \multicolumn{2}{|c|}{ Debit Pengambilan $\left(\mathrm{m}^{3} / \mathrm{s}\right)$} & \multicolumn{2}{|c|}{ Tingkat Layanan (\%) } \\
\hline & & & $\begin{array}{c}\text { Keandalan } \\
90 \%\end{array}$ & $\begin{array}{c}\text { Keandalan } \\
95 \%\end{array}$ & Per Bendungan & Total \\
\hline Cikawari 2A & 25 & 1,78 & 0,489 & 0,419 & 6,10 & 28,58 \\
\hline Cikawari 5A & 45 & 3,61 & 0,130 & 0,113 & 22,48 & \\
\hline
\end{tabular}

\section{Pemilihan Alternatif Pembangunan}

Hasil simulasi waduk menunjukkan bahwa pembangunan waduk kaskade menghasilkan tingkat layanan yang lebih kecil dibandingkan dengan pembangunan waduk tunggal sehingga alternatif waduk kaskade tidak dipertimbangkan lebih lanjut. Simulasi waduk kembali dilanjutkan untuk alternatif Waduk Tunggal Cikawari 2A dan Waduk Tunggal Cikawari 5A pada berbagai tinggi pelimpah untuk mencari komposisi yang mampu memberikan tingkat layanan terbesar pada tahun 2020, 2025, dan 2040. Hasil analisis pada Tabel 6 menunjukkan bahwa peningkatan tinggi pelimpah sebesar $5 \mathrm{~m}$ pada Waduk Cikawari 5A mampu menambah tingkat layanan sebesar 3\%, dimana nilai ini lebih besar dari peningkatan layanan Waduk Cikawari 2A yang hanya sebesar $1,5 \%$ pada penambahan tinggi pelimpah yang sama. Hal ini sejalan dengan peningkatan kapasitas tampungan Waduk Cikawari 5A yang lebih besar dari Waduk Cikawari 2A, dimana penambahan tinggi pelimpah sebesar $5 \mathrm{~m}$ mampu menambah tampungan Waduk Cikawari 5A lebih dari 40\%. Namun demikian, kapasitas tampungan yang terbatas membuat Waduk Cikawari 5A hanya mampu memberikan tingkat layanan sebesar $22,47 \%$ dengan ketinggian pelimpah $45 \mathrm{~m}$ dimana tingkat layanan ini dapat dicapai oleh Waduk Cikawari 2A dengan ketinggian pelimpah di bawah $35 \mathrm{~m}$. Mempertimbangkan kondisi ini, alternatif pembangunan Waduk Cikawari 5A menjadi kurang efektif sehingga alternatif Waduk Tunggal Cikawari 2A dengan tinggi pelimpah $45 \mathrm{~m}$ dipilih sebagai alternatif waduk untuk memenuhi kebutuhan air Kota Bandung bagian Utara.

Namun, alternatif terpilih ini belum mampu memenuhi seluruh kebutuhan (tingkat layanan $100 \%$ ), namun hanya mampu menghasilkan tingkat layanan terbesar, yaitu sebesar 30,40\%, 30,25\%, dan $30,15 \%$ pada tahun 2020, 2025, dan 2040 secara berurutan. Dengan demikian, diperlukan alternatif lain untuk mencapai target pemenuhan yang diharapkan

\section{Pola Operasi Waduk Tunggal Cikawari 2A}

Analisis pola operasi waduk (POW) dilakukan pada alternatif pembangunan waduk terpilih, yaitu waduk tunggal Cikawari 2A dengan tinggi bendungan $45 \mathrm{~m}$. POW dibuat untuk memeriksa kesiapan waduk dalam melayani kebutuhan air pada tiga kondisi pengoperasian, yaitu kondisi tahun kering, normal, dan basah.

Penentuan kondisi kering, normal, dan basah dilakukan dengan menentukan kurva durasi untuk curah hujan tahunan pada periode tahun 1998 sampai dengan 2018 seperti dapat dilihat dalam 
Gambar 12. Kurva durasi hujan digunakan mengingat bahwa data pencatatan debit yang tersedia selama 6 tahun (tahun 2003-2009) sehingga tidak memadai untuk dibuat kurva durasi. Berdasarkan kurva durasi yang diperoleh, ditetapkan bahwa tahun basah terjadi pada tahun 2013, tahun normal pada tahun 2009, dan tahun kering pada tahun 2008. Selanjutnya data hujan pada tahun-tahun tersebut diubah menjadi debit sintentik untuk mensimulasikan pengoperasian waduk pada kondisi tahun basah, normal, dan kering.

Sementara itu, debit outflow yang digunakan adalah nilai debit keandalan waduk 95\% sebesar $0,562 \mathrm{~m}^{3} / \mathrm{s}$ dari simulasi waduk Cikawari 2A dengan tinggi bendungan $45 \mathrm{~m}$ dengan volume tampungan total sebesar $7.830 .000 \mathrm{~m}^{3}$, dan prediksi volume tampungan efektif sebesar $6.353 .162 \mathrm{~m}^{3}$. Profil elevasi muka air waduk pada ketiga kondisi operasi waduk disajikan pada Gambar 13.

Berdasarkan hasil simulasi waduk di atas, terlihat bahwa pada kondisi kering terjadi kegagalan di akhir periode operasi waduk karena elevasi muka air waduk tidak dapat kembali mendekati elevasi awal. Maka dari itu, debit pengambilan pada tahun kering perlu dikurangi menjadi $0,440 \mathrm{~m}^{3} / \mathrm{s}$ agar air waduk dapat kembali ke elevasi mendekati kondisi awal pada akhir tahun dengan resiko berkurangnya jumlah persentase penduduk yang terlayani menjadi $24 \%$ pada tahun 2020. Pengurangan nilai debit pengambilan ini menghasilkan profil elevasi muka air waduk seperti pada Gambar 14.

Tabel 6 Alternatif pembangunan waduk

\begin{tabular}{c|c|c|c|c|c|c}
\hline \multirow{2}{*}{$\begin{array}{c}\text { Alter- } \\
\text { natif }\end{array}$} & Waduk & $\begin{array}{c}\text { Volume } \\
\text { Tampungan } \\
\left(\mathrm{m}^{3}\right)\end{array}$ & Tahun & $\begin{array}{c}\text { Tingkat } \\
\text { Layanan } \\
(\%)\end{array}$ & $\begin{array}{c}\text { Jumlah } \\
\text { Penduduk } \\
\text { (orang) }\end{array}$ & $\begin{array}{c}\text { Debit Kebutuhan } \\
\text { Domestik }+\end{array}$ \\
\hline Perkotaan $\left(\mathrm{m}^{3} / \mathrm{s}\right)$
\end{tabular}




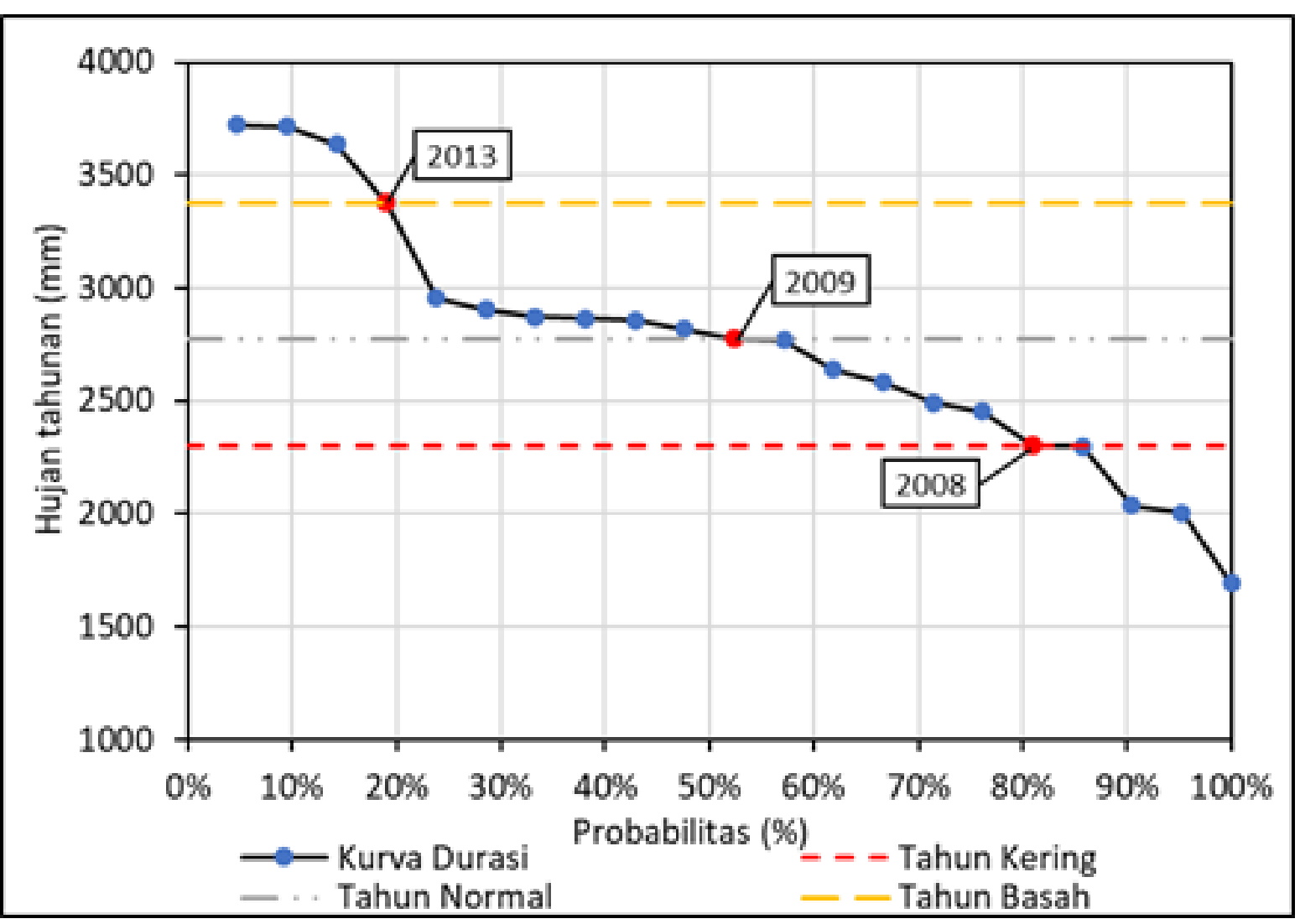

Gambar 12 Kurva Durasi Curah Hujan Tahunan

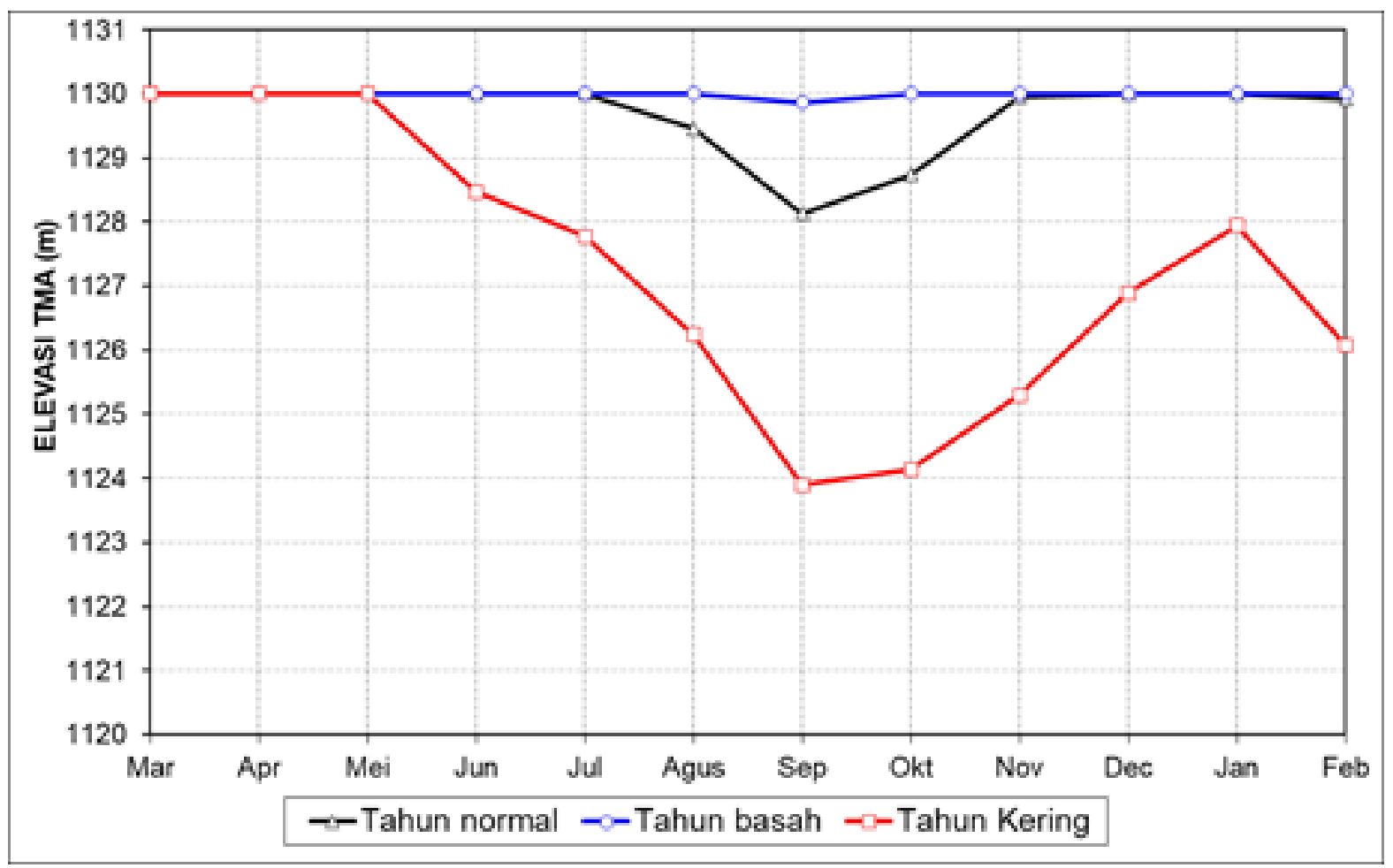

Gambar 13 POW Cikawari 2A Tinggi Pelimpah $45 \mathrm{~m}$ dengan debit pengambilan 0,562 $\mathrm{m}^{3} / \mathrm{s}$ 


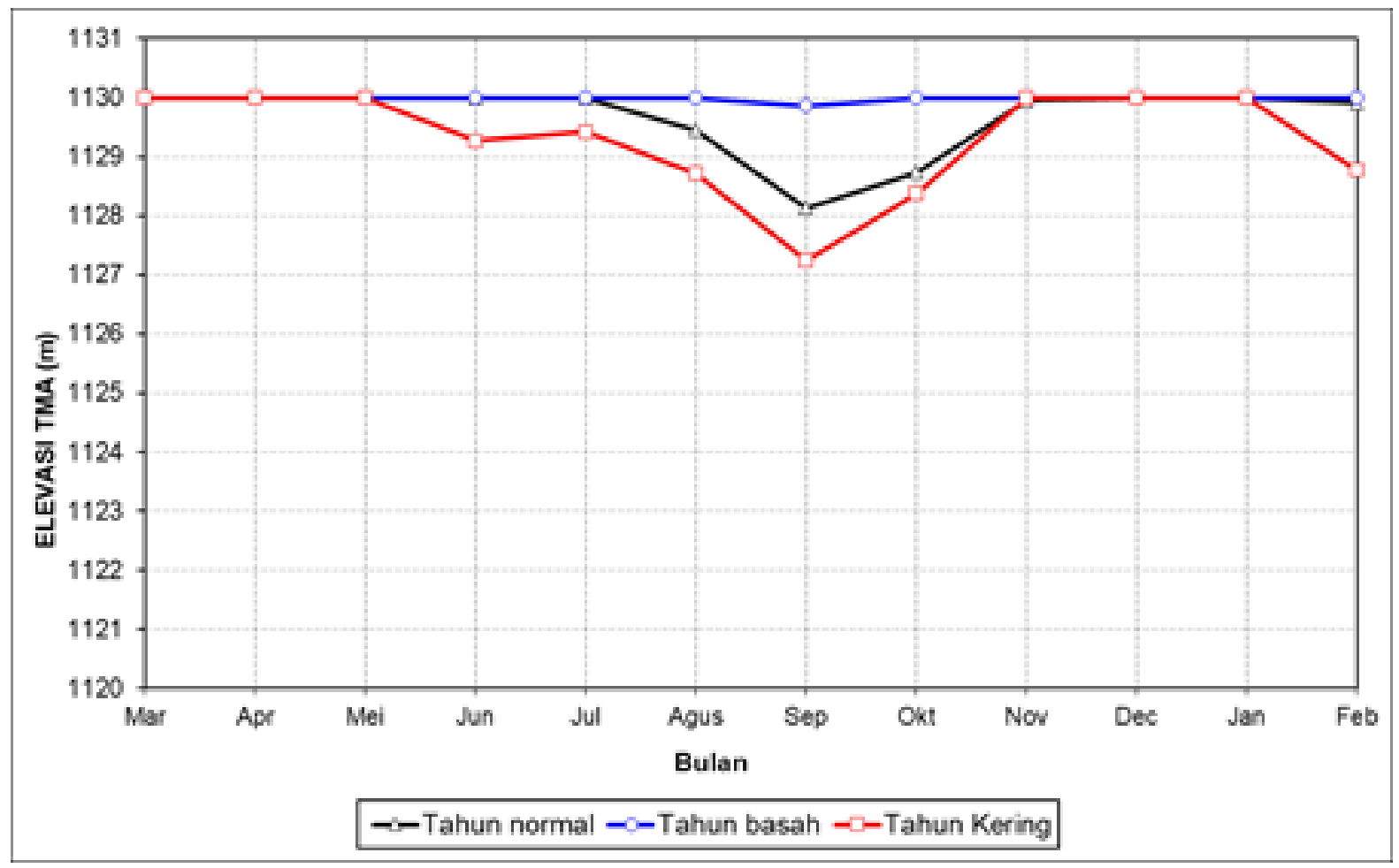

Gambar 14 POW Cikawari 2A Tinggi Pelimpah $45 \mathrm{~m}$ dengan debit pengambilan 0,440 m³/s

\section{KESIMPULAN}

Hasil analisis ketersediaan air menunjukkan ketidakmampuan sungai untuk mencukupi kebutuhan air Kota Bandung secara penuh sehingga diperlukan pembangunan waduk Cikawari 2A dan Cikawari 5A. Berdasarkan hasil simulasi pada berbagai skenario, alternatif waduk tunggal Cikawari 2A dengan tinggi pelimpah $45 \mathrm{~m}$ merupakan alternatif yang terpilih karena mampu meningkatkan debit layanan menjadi $0,562 \mathrm{~m}^{3} / \mathrm{s}$. Alternatif ini mampu memenuhi kebutuhan air untuk 30,4\% dari jumlah penduduk pada tahun 2020 , dan sedikit menurun menjadi $30,15 \%$ pada tahun 2040.

Hasil pola operasi waduk menunjukkan pada kondisi kering terjadi kegagalan di akhir periode operasi waduk karena elevasi muka air waduk tidak dapat kembali ke elevasi awal. Maka dari itu, debit pengambilan pada tahun kering harus dikurangi menjadi 0,440 $\mathrm{m}^{3} / \mathrm{s}$ agar air waduk kembali ke elevasi mendekati awal dengan resiko berkurangnya jumlah persentase penduduk yang terlayani menjadi $24 \%$ pada tahun 2020. Pemanfaatan waduk belum mampu memenuhi seluruh kebutuhan air Kota Bandung bagian Utara sehingga alternatif penyediaan sumber air baku lain masih perlu diupayakan agar dapat memenuhi kebutuhan air yang diharapkan.

\section{UCAPAN TERIMA KASIH}

Ucapan terima kasih penulis sampaikan kepada tim PT. Rencana Cipta Mandiri yang telah bersedia menyediakan kajian awal serta data yang diperlukan dalam penelitian ini.

\section{DAFTAR PUSTAKA}

Badan Pusat Statistik (BPS). (2010). Pedoman Penghitungan Proyeksi Penduduk dan Angkatan Kerja. Jakarta: Badan Pusat Statistik.

Badan Pusat Statistik (BPS) Kota Bandung. (2019a). Jumlah Penduduk dan Laju Pertumbuhan Penduduk di Kota Bandung 2011 - 2016. https://bandungkota.bps.go.id (diakses pada 10 Desember 2019).

Badan Pusat Statistik (BPS) Kota Bandung. (2019b). Jumlah Penduduk Kota Bandung, 2015-2019 (Jiwa). https://bandungkota.bps.go.id (diakses pada 10 Desember 2019).

Badan Meteorologi, Klimatologi, dan Geofisika. (2019). Data Online, Pusat Database - BMKG: http://dataonline.bmkg.go.id/data_iklim (diakses pada 10 Desember 2019)

Christopher, C. (2020). Studi Kelayakan Waduk Cikawari 2A dan 5A Dalam Rangka Pemenuhan Kebutuhan Air Kota Bandung Utara. Skripsi Sarjana. Bandung: Universitas Katolik Parahyangan 
Crawford, N. H. (1985). Small Hydropower, Hydrological Methodology without Streamflow Data. California, USA.

Euroconsult Mott MacDonald. (2014). Bulk Water Supply Master Plan. Bandung: Bappeda Jawa Barat - Bappenas.

Julian, M. M., Nishio, F., Poerbandono, \& Ward, P. J. (2011). Simulation of River Discharges in Major Watersheds of Northwestern Java From 1901 To 2006. International Journal of Technology, 1, 3746.

Kementerian Pekerjaan Umum dan Perumahan Rakyat. (2017). Modul Hidrologi, Kebutuhan dan Ketersediaan Air. Bandung

Kuntoro, A. A., Putro, A. W., Kusuma, M. S. B., \& Natasaputra, S. (2017). The effect of land use change to maximum and minimum discharge in Cikapundung River Basin. In AIP Conference Proceedings (Vol. 1903, No. 1, p. 100011). AIP Publishing LLC. DOI:10.1063/1.5011621

Maria, R. \& Lestiana, H. (2014). Pengaruh Penggunaan Lahan terhadap Fungsi Konservasi Air Tanah di Sub-DAS Cikapundung. RISET Geologi dan Pertambangan, 24(2), 77-89. DOI:10.14203/risetgeotam2014.v24.85

Nurcahyo, H., Soekarno, I., Hadihardaja, I. K., \& Rosyidie, A. (2016). Hydrologic Alteration in Watershed Using Flow Duration Curve, Case Study Upper Citarum Watershed, Indonesia. International Proceedings of Chemical, Biological and Environment Engineering, Volume of IPCBEE. DOI: 10.7763/IPCBEE. 2016. V94. 24
Peraturan Menteri Pekerjaan Umum dan Perumahan Rakyat Republik Indonesia Nomor 27 tahun 2015 tentang Bendungan.

Rencana Cipta Mandiri. (2019). Laporan Hidrologi dan Hidraulika Detail desain Tahap I Bendungan Cikapundung. Bandung: PT. Rencana Cipta Mandiri.

Rubianto. (2003). Kajian Pengelolaan Sumber Air Baku di Kota Bandung dan Kabupaten Bandung. PILAR, 12(2), 108-121

Sabar, A. (2006). Prospek Kontribusi DAS Cikapundung Hulu Memenuhi Laju Permintaan Sumber Air Baku Metropolitan Bandung. Media Komunikasi Teknik Sipil, 14(2) ed. XXXV, 169-178. https://doi.org/10.14710/mkts.v14i2.3944

Tanuwijaya, Z.A.J., Hendarmawan, Sudradjat, A., \& Kuntjoro, W. (2018). Karakteristik Musiman Debit Sungai Cikapundung di Kawasan Bandung Utara, Jawa Barat. Bulletin of Scientific Contribution: GEOLOGY, 16(1), 39-46.

Wibowo, M. (2005). Analisis Pengaruh Perubahan Penggunaan Lahan terhadap Debit Sungai (Studi Kasus Sub-DAS Cikapundung Gandok, Bandung). Jurnal Teknik Lingkungan P3TL-BPPT, 6(1), 283290. DOI: 10.29122/jtl.v6i1.328

Yoshida, K., Azechi, I., Hariya, R., Tanaka, K., Noda, K., Oki, K., Hongo, C., Honma, K., Maki, M., \& Shirakawa, H. (2013). Future Water Availability in the Asian Monsoon Region: A Case Study in Indonesia. Journal of Developments in Sustainable Agriculture, 8, 25-31. 